Karolina DziUbata (D) https://orcid.org/0000-0003-0157-1502

Uniwersytet im. Adama Mickiewicza w Poznaniu

\title{
Stereotypizując fryzurę. Wyobrażenia na temat włosów w doświadczeniach osób noszących dredy w Polsce
}

\section{Wprowadzenie}

W lutym 2020 roku na 92. ceremonii wręczenia Oscarów statuetkę Akademii Filmowej w kategorii krótkometrażowy film animowany otrzymała produkcja Hair Love Matthew A. Cherry'ego przedstawiająca relację między ojcem a córką, opowiedzianą przez pryzmat jej problemów z włosami ${ }^{1}$. Miesiąc później tzw. lockdown ${ }^{2}$ i społeczna kampania \#zostańwdomu doprowadziła do tymczasowego zamknięcia lokali świadczących usługi wymagające bezpośredniego kontaktu z klientem, w tym salony fryzjerskie. Brak dostępu do tej usługi sprawił, że najpierw celebryci, a później także „zwykli” użytkownicy internetu zaczęli golić swoje włosy i dzielić się tym doświadczeniem w mediach społecznościowych. Dla wielu kobiet ogolona głowa stała się manifestem ciałopozytywności i podważeniem społecznie skonstruowanych kategorii męskości i kobiecości³.

Te oraz inne wydarzenia i teksty kultury ${ }^{4}$ sprawiły, że powróciłam do własnych zainteresowań związanych ze znaczeniem ludzkich włosów oraz do

\footnotetext{
${ }^{1}$ Zob. http://www.matthewacherry.com/hair-love/ [dostęp: 25.05.2020].

${ }^{2}$ Rządowe rozporządzenia ograniczające kontakty międzyludzkie i mobilność społeczną wprowadzone w celu walki z epidemią wirusa SARS-CoV-2 wywołującego chorobę COVID-19.

${ }^{3}$ Zob. https:/ / www.thecut.com/2020/04/quarantined-people-talk-about-shaving-theirheads.html [dostęp: 27.05.2020].

${ }^{4}$ M.in. film Wtasnymi rękoma. Historia Madame C.J. Walker, http:/ / madamcjwalker.com/about/ [dostęp: 25.05.2020]; książka Debory Feldman Unorthodox. Jak porzucitam świat ortodoksyjnych
} 
etnologicznych badań terenowych, które prowadziłam w ramach pracy magisterskiej. Ich zasadniczym celem było poznanie wyobrażenia na temat włosów z perspektywy osób noszących dredy w Polsce. Celem tego artykułu jest zaprezentowanie wyników tych badań oraz osadzenie ich w szerszym kontekście. Dlatego też jego pierwsza część stanowi przegląd badań nad dredami. Jest to także wprowadzenie teoretyczne do części analitycznej, w której odnoszę się do kontekstu polskiego, bazując przy tym na wynikach wywiadów etnograficznych prowadzonych $\mathrm{w}$ ramach pracy magisterskiej. $\mathrm{W}$ artykule szukam odpowiedzi na pytania badawcze: jakie wyobrażenia nakładane są na osoby noszące dredy w Polsce? Skąd wynikają? Jak „dredziarze" postrzegają dotykające ich stereotypy? Co dredy oznaczają dla ich użytkowników?

\section{Zainteresowanie włosami w naukach społecznych}

Zainteresowanie dredami wpisuje się w szerszą kategorię badań nad symboliką włosów. Według Edmunda Leacha (1958) praktyki związane z włosami są rozpowszechnionymi na całym świecie elementami zachowania rytualnego, a antropologiczne próby ich analizy mają historię sięgającą końca XIX wieku. Na semantyczną naturę włosów zwrócił uwagę już Edward Burnett Tylor, pisząc w Cywilizacji pierwotnej (1898) o rytualnym obcinaniu włosów, oraz holenderski etnolog George Alexander Wilken (1886) w eseju poświęconym roli fryzury w ceremoniach pogrzebowych (zob. Leach 1958: 149). Arnold Van Gennep przedstawił rolę włosów w obrzędach przejścia (1909, wyd. pol. 2006: 167-168). Włosy, nawet jeżeli nie stanowiły głównego problemu badawczego, pojawiały się także w pracach innych antropologów, m.in. Bronisława Malinowskiego (1929, wyd. pol. 1957: 273, 380-381, 386-387) czy Mary Douglas (1970, wyd. pol. 2004). W ostatnich dekadach powstało wiele publikacji dotyczących symbolicznego znaczenia ludzkich włosów (zob. Rooks 1996; Hiltebeitel, Miller 1998; Banks 2000; Tarlo 2016), a także samych dredów (Agwuele 2016).

Szeroko zakrojone zainteresowanie włosami w naukach społecznych pojawiło się na początku lat 50. XX wieku za sprawą amerykańskiego psychologa Charlesa Berga. Jego publikacja The Unconscious Significance of Hair (1951) stała się zarzewiem interdyscyplinarnej dyskusji na temat znaczenia ludzkich włosów. Berg stwierdził istnienie korelacji pomiędzy fryzurą a seksualnością człowieka, w której włosy są uniwersalnym i nieświadomym symbolem ludzkich genitaliów, a ich obcinanie stanowi akt symbolicznej kastracji.

Twierdzenie to wywołało gwałtowną reakcję badaczy społecznych. Leach (1958) skrytykował wiarygodność dowodów psychoanalitycznych i podważył wnioski, które Berg wyciągnął z etnograficznych opisów Malinowskiego. Antropolog zaproponował własną koncepcję (Leach 1958: 154), którą można ująć

Żydów (2020); dyskusja wokół dredów pisarki i noblistki Olgi Tokarczuk: https://www. newsweek.pl/kultura/olga-tokarczuk-noblistka-i-dredy-skad-taka-fryzura/nc92vjx [dostęp: 27.11.2020]. 
następująco: w sytuacjach rytualnych (1) długie włosy oznaczają brak ograniczeń w sferze seksualności, (2) krótkie, częściowo ogolone lub związane włosy wyrażają ograniczoną seksualność, (3) całkowicie ogolona głowa symbolizuje celibat.

Jedenaście lat później Christopher Hallpike (1969) za pomocą przykładu ascetycznych praktyk muzułmańskich mnichów próbował obalić tezy obu naukowców. Długie włosy, splątane w dredy, żyjących w celibacie fakirów przeczyły tezom Leacha i Berga. We własnej koncepcji Hallpike (1969: 260) położył nacisk na zależność pomiędzy fryzurą a kontrolą społeczną: „długie włosy związane są z przebywaniem poza społeczeństwem, a obcięte włosy symbolizują powrót do społeczeństwa lub życie w szczególnej dyscyplinie w obrębie społeczeństwa". Podobne stanowisko zajęła Mary Douglas (2004: 119).

W 1987 roku kanadyjski socjolog Anthony Synnott stwierdził, że określone fryzury mogą być symbolem indywidualnej i grupowej identyfikacji oraz ważnym środkiem ekspresji i komunikacji. Wyróżnił trzy strefy owłosienia o różnym znaczeniu symbolicznym: włosy na głowie, na twarzy oraz na reszcie ciała. Według jego teorii przeciwności (potrójnego przeciwieństwa) istnieją trzy opozycje, które manifestują się poprzez praktyki związane z włosami: (1) kobiety i mężczyźni mają inne fryzury, (2) przeciwstawne ideologie wyrażane są poprzez odmienne fryzury, (3) włosy na głowie są przeciwieństwem włosów na ciele (Synnott 1987: 382). Synnott zaznaczył jednak, że jego koncepcja nie jest założeniem uniwersalnym - ma na celu jedynie podkreślenie istniejących norm i tendencji oraz wynikających z nich wyobrażeń i stereotypów.

W polskiej literaturze naukowej włosom poświęcony jest m.in. artykuł Poza społeczeństwem - w pobliżu boskości. Przyczynek do rozważań nad symbolika włosów (Tomicki 1987), którego celem było rozszerzenie i uzupełnienie teorii Hallpike’a, a także monografia Opowieść o włosach. Zwyczaje - rytuały - symbolika (Banek 2010). Książce tej bliżej jednak do katalogu zwyczajów, obrzędów i wierzeń dotyczących włosów niż ich szczegółowej analizy. Wartym uwagi jest również artykuł Symbolika włosów i manipulowanie włosami w kulturze ludowej (Targońska 1998), którego autorka analizuje zwyczaje dotyczące włosów w kontekście obrzędowości rodzinnej.

\section{Antropologia dredów}

Osoby noszące dredy można odnaleźć w wielu zakątkach na świecie. Fryzura ta jest określana w różny sposób oraz pełni różne funkcje. W zależności od miejsca i kontekstu może symbolizować religijność jednostki (Obeyesekere 1981; Olivelle 1998; Bogin 2008), polityczny manifest (Ashe 2015), żałobę (Watson 1998) lub po prostu panującą modę. Motywacje jednostek do wykonania takiej fryzury nie zawsze wiążą się z konkretną ideologią czy polityką, niemniej nie jest ona zupełnie wolna od znaczeń. Nazwa „dredy” pochodzi od angielskiego terminu dreadlocks, powstałego z połącznia słów dread (strach, bać się, straszny) oraz lock (pukiel włosów, kędzior). Termin ten odnosi się do splątanych, sfilcowanych bądź zaplecionych pęków włosów na głowie. Sanskryckie słowo użyte na 
określenie dredów to jaTaa, które oznacza „nosić skręcone pęki włosów” (Ashe 2015: 36); w języku wolof (Senegal) - ndiange, co można przetłumaczyć na „mocne włosy” (Ashe 2015: 41-44); natomiast u Jorubuów jest to słowo dada, oznaczające m.in. dziecko urodzone z naturalnie splątanymi włosami, których nie można rozczesać (Agwuele 2016: 5).

Wśród antropologów symboliką splątanych włosów zajmował się m.in. Gananath Obeyesekere. W swoich notatkach terenowych ze Sri Lanki napisał, że uderzył go widok skołtunionych włosów powiewających na wietrze podczas ekstatycznego tańca syngaleskiej kapłanki (Obeyesekere 1981: 6). W książce Medusa's Hair. An Essay on Personal Symbols and Religious Experience antropolog przedstawił sposób artykułowania indywidualnych doświadczeń poprzez określone symbole kulturowe. Dokonał analizy znaczenia przypisywanego włosom-dredom przez kobiety, które w wyniku doświadczeń życiowych zostały kapłankami w syngaleskiej Kataragamie. Karunavati została opętana przez boga Huniyana, który obiecał obdarować ją siedmioma splątanymi pękami włosów, jeżeli wyrzeknie się swojej seksualności. Nandavati wyznała antropologowi, że jej włosy w ciągu tygodnia po prostu się skołtuniły i przybrały kształt podobny do węży. Za radą kapłana kobieta udała się do świątyni Kataragama, gdzie miała skonsultować swoją decyzję z bogami i zostać kapłanką. Włosy Manci Nony zaczęły kołtunić się od momentu wpadnięcia $w$ trans podczas pracy przy maszynie do szycia. Wierząc, że jej sześć dredów było darem od boga Skandy, wyruszyła do Kataragamy. Kobiety postrzegały swoje włosy jako esencję życia, traktowały je z nabożnością i nie pozwalały na dotykanie ich przez innych ludzi. Na tej podstawie badacz stwierdził, że „kompleks doświadczeń indywidualnych jednostki krystalizuje się w symbolach publicznych" (Obeyesekere 1981: 13).

Indolog Patrick Olivelle analizował dredy w kontekście struktury i kontroli społecznej. Noszone przez hinduskich ascetów, pustelników i banitów politycznych dredy są dla niego wyrazem fizycznej separacji od społeczeństwa i cywilizowanego życia oraz symbolizują ich relacje z duchami i bóstwami. Długie i poplątane w wyniku braku higieny włosy świadczą o całkowitym zobojętnieniu na wygląd, odrzuceniu społecznych norm zachowania w kwestii własnego ciała oraz ascetycznym wycofaniu się ze społeczeństwa (Olivelle 1998: 23. 26). Fryzura miała też pełnić funkcję wyróżnika kulturowego - odróżniała wędrownych ascetów od wyznawców sikhizmu, którym wiara nakazuje regularnie myć i czesać włosy. Różnicującą funkcję dredów zauważono również wśród buddyjskich kapłanów tantrycznych, którzy w ten sposób odróżniali się od mnichów tybetańskich (Bogin 2008), a także u wojowników masajskich (Saitoi, Beckwith 1980: 126-129).

Interesujące zjawisko związane ze splątanymi włosami zaobserwował także amerykański antropolog James L. Watson. Podczas badań w Hongkongu w latach sześćdziesiątych zobaczył „długowłosego ducha” - nędzarza przebywającego w stanie permanentnej żałoby spowodowanej śmiercią ich rodzin z rąk komunistów (Watson 1998: 178). Mieszkańcy wsi San Tin, w której antropolog prowadził badania, nadawali tej fryzurze dodatkowe znaczenie, związane z wizerunkiem tzw. głodnych duchów. W południowych Chinach ciała zmarłych po kilku latach 
od pogrzebania były ekshumowane w celu ich oczyszczenia z pozostałego mięsa, włosów i paznokci, a następnie ponownie chowane. Tym, co budowało skojarzenie między ekshumowanymi szczątkami, „głodnymi duchami”, a długowłosymi nędzarzami, były dredy (Watson 1998: 188).

Globalny fenomen dredów ma swoje początki na Jamajce. W jaki sposób się tam znalazły? Według Bertrama Ashego istnieje kilka wyjaśnień. Jedno z nich mówi o zainspirowaniu się przez współczesnych rasta fotografiami zmieszczonymi niegdyś w jamajskiej prasie, które przedstawiały Afrykanów w długich dredach. Niektórzy twierdzą, że zdjęcia przedstawiały Oromów, Somalijczyków albo Masajów. Inni uważają, że byli to zwolennicy pochodzącego z plemienia Kikuju kenijskiego polityka Jomo Kenyatty, uczestników powstania Mau Mau lub hinduskich pustelników, którzy podobno przebywali na Jamajce w 1910 roku.

Według ostatniej wersji na fotografiach tych znajdowali się poplecznicy Hajle Syllasjego I, ostatniego cesarza Etiopii, który współcześnie jest jednym z głównych symboli religijnego ruchu rastafari. Co ciekawe, ani cesarz Hajle Syllasje, ani pochodzący z Jamajki Leonard Howell, znany później jako „Pierwszy Rasta”, nie mieli dredów, lecz charakterystyczne długie brody. Dredy jako wyróżnik ruchu rastafariańskiego zostały spopularyzowane w latach 50. XX wieku za sprawą organizacji Youth Black Faith, która kierowała się biblijnym oświadczeniem Nazarejczyków o nieobcinaniu swoich włosów. Zaczęły służyć identyfikacji, manifestacji solidarności i społecznej prowokacji (Ashe 2015: 37-44).

W polskim kontekście kulturowym rozważania na temat znaczenia dredów jako fryzury powstałej ze sfilcowanych włosów muszą zostać powiązane z tzw. kołtunem. W szesnastowiecznej Polsce terminem „kołtun” określano silnie splątane włosy w postaci pęku, sznurów bądź czegoś na kształt czapki powstałej w wyniku długotrwałego braku higieny ze sfilcowanych włosów posklejanych brudem i łojem (Cukierska 2014: 18). „Najmłodszy” przykład polskiego kołtuna został zaobserwowany w roku 2013 (Pruszyński et al. 2013). Nazwa zjawiska pochodzi najprawdopodobniej od słowa 'kiełtanie się' oznaczającego kołysanie się - w tym przypadku brudnych, splątanych włosów (Brückner 1927: 248). Początkowo jednak kołtun nie był postrzegany jako efekt braku higieny osobistej. Wiązano go przede wszystkim z chorobą, chociaż i to nie było oczywiste, o czym pisze Anna Targońska (1998: 167): „Pierwotnie nie uważano go za chorobę, lecz traktowano jako jej emanację. Wychodzono z założenia, iż każdy człowiek posiada w sobie uśpioną dolegliwość, która zruszona uzewnętrzniała chorobę oraz powodowała zwijanie się włosów i tworzenie kołtuna".

Niekiedy kołtun traktowano jako talizman, który miał chronić swojego właściciela przed chorobami czy urokiem rzuconym przez czarownicę (Gąsiorowski 2013: 3). Kołtun zapuszczano celowo, by choroba „uciekała” na zewnątrz i zamiast ciała „atakowała” włosy. Zdarzało się, że traktowano go jako osobną istotę nadprzyrodzoną posiadającą własną sprawczość. Kołtun mógł wymagać czegoś od swojego „żywiciela”, a jeśli tego nie dostał, mógł zadziałać na jego niekorzyść. Istniało również rozróżnienie na kołtun męski i żeński. Kołtun męski (samiec) przybierał kształt zwisających wokół głowy splątanych sznurów włosów. Kołtun 
żeński (samica) występował pod postacią zbitej, podobnej do skorupy lub czapki masy włosów (Cukierska 2014: 23). W literaturze etnograficznej można odnaleźć opisy przedstawiające sposoby zadawania i pozbywania się kołtuna (Udziela 1891: 204; Cukierska 2014: 22).

Jednym z badaczy zajmujących się omawianym zjawiskiem był Józef Dietl, który w 1862 roku opracował genezę sfilcowanego kłębu włosów i dowiódł braku związku między jego obcięciem a chorobami tych, którzy go nosili. Choć obcinanie kołtunów oraz zalecenie o częstym myciu głowy i czesaniu włosów poskutkowało zanikiem kołtuna, jakiś czas po apelu badacza odnotowywano jeszcze sporadyczne przypadki zapuszczania spilśnionych włosów w różnych częściach Polski. Przekonałam się o tym w 2016 roku podczas badań terenowych dotyczących praktykowania krajobrazu kulturowego na Biskupiźnie. Spotkałam tam urodzoną w 1954 roku mieszkankę Żychlewa, która opowiadała o tym, jak jej babcia cierpiała na „kotun”:

[Babcia] była 1900 rocznik. (...) Wie pani, tu za bogato nie było. (...) Babcia opowiadała, ale nie wie dlaczego, że dostała, jak miała dziesięć czy dwanaście lat kotuny. Włosy jej się... nie twierdzę, żeby nie od mycia. Ale może, no nie wiem. Bo miała anemię, wszystko. I ojca wtedy nie miała. I jak ona wyglądała... (...) I potem jak ścinali, bo już miała jako perukę i musieli ściąć, to zemdlała. (...) Najgorsza bieda u nas była w 1910 roku. (...) Włosy się, tak jak filc, sfilcowały się na głowie. (...) $\mathrm{Z}$ biedy to się chyba zrobiło, ja czuję. Albo choroba była? Ja wiem, że miała anemię.

Kołtun był dla kobiety tematem wstydliwym - nie chciała zbyt wiele opowiadać o trudnych warunkach bytowych swojej rodziny. Była świadoma tego, że splątanie włosów babci mogło wynikać z braku higieny, jednak nie wykluczała innych możliwości, takich jak choroba czy bieda. Podczas drugiej rozmowy, w której uczestniczyły dwie inne osoby, padło pytanie, czy „kotun” rzeczywiście jest tylko splątanymi, brudnymi włosami, czy może dolegliwością wewnętrzną. Jedna z kobiet obecnych przy spotkaniu zapytała: „Ale to na pewno na głowie? Bo ja słyszałam, że to jakby na żołądku!". Moi rozmówcy widzieli w nim nie tylko brak higieny, ale także choroby trawiące ciało od wewnątrz, których sfilcowana masa wyrastająca z głowy była tylko zewnętrznym objawem.

Powyższe przykłady zdają się potwierdzać tezę Olivelle’a (1998: 31), według której nie ma jednego i uniwersalnego znaczenia włosów, a ten sam symbol może w tych samych bądź różnych kontekstach jednocześnie mieć więcej niż jedno znaczenie. Dotyczy to również dredów - jak dowodzi Ashe (2015: 36) - taką fryzurę nosiły „plemiona germańskie, Wikingowie, mieszkańcy wysp Pacyfiku, Aztekowie, wcześni chrześcijanie, członkowie Baye Fall z Senegalu - pytanie nie brzmi, kto nosi dredy. Pozostaje pytanie, kto ich nie nosił?". W każdym z tych miejsc dredy są częścią wierzeń i praktyk, mają inne znaczenie, są inaczej wykonywane i nazywane. Wyobrażenia na temat dredów rodzą niekiedy nieporozumienia komunikacyjne, a nawet konflikty, które znalazły się w centrum moich badań nad społeczno-kulturowymi aspektami noszenia dredów w Polsce. 


\section{Dredy w Polsce: muzyka, władza i płeć kulturowa}

Na studiach magisterskich w Instytucie Antropologii i Etnologii UAM (wtedy jeszcze Instytutu Etnologii i Antropologii Kulturowej) interesowałam się kulturowymi praktykami dotyczącymi włosów i fryzury, a szczególnie funkcjonującymi w naszym społeczeństwie wyobrażeniami na temat dredów. W ciągu sześciu lat noszenia dredów spotykałam się ze zróżnicowanymi reakcjami i pytaniami, nie zawsze uprzejmymi, które zadawali mi zarówno bliscy, jak i przypadkowo spotkani ludzie. Dlatego też na podstawie własnych doświadczeń oraz badań przeprowadzonych w 2017 roku przygotowałam i obroniłam pracę magisterską pt. Stereotypizując fryzure. Społeczno-kulturowe aspekty noszenia dredów w Polsce, na bazie której powstał ten artykuł.

Podczas badań trwających od grudnia 2016 do maja 2017 roku przeprowadziłam dziesięć wywiadów etnograficznych ${ }^{5}$. Próba ta jest zdecydowanie za mała, by formułować na jej podstawie ogólne wnioski, jednak pozwoliła mi na rozpoznanie zjawisk związanych z praktykowaniem dredów w Polsce. Moimi rozmówcami stały się osoby między 20. a 31. rokiem życia. Większość z nich (siedem osób) stanowili studenci (M01, M02, M03, M04) i studentki (K02, K03, K04, K06) uczący się w Poznaniu, Lesznie i Krakowie. Jedna osoba pracowała na pełen etat (K05). Jedna prowadziła własną działalność gospodarczą (K01). Spotkania odbywały się we Wschowie, w Poznaniu, Gnieźnie, Sławie, Zielonej Górze, Stęszewie i Krakowie. Pierwsze rozmowy przeprowadziłam z osobami z najbliższego środowiska. Stali się oni moimi „odźwiernymi”, którzy pomagali wskazać kolejnych potencjalnych rozmówców.

Wywiady zostały przeprowadzone w różnych przestrzeniach. Z niektórymi spotkałam się w ich domach, $\mathrm{z}$ innymi umawiałam się w kawiarni lub w barze, a także online. Moje pytania dotyczyły przede wszystkim motywacji, które skłoniły daną osobą do wykonania dredów. Pytałam o to, kiedy je zrobiła i z jakiego powodu. Interesowało mnie, czy była to spontaniczna decyzja, czy poprzedzały ją przygotowania, czy dredy zostały zrobione przez profesjonalistę w salonie, czy może w domu przez znajomego. Pytałam o zmiany, jakie nastąpiły po ich zrobieniu, o reakcję rodziny, przyjaciół, obcych, a także o ogólną rolę, jaką włosy odgrywają w ich życiu, czy są dla nich ważne. Interesowały mnie również doświadczenia związane z postrzeganiem dredów przez innych ludzi oraz opinie rozmówców na ten temat. Zastanawiałam się, czy stosowano wobec nich określone wyobrażenia i stereotypy, a jeżeli tak, to jaki mieli do nich stosunek.

Pomysł na zmianę fryzury moi rozmówcy podejmowali najczęściej kilka lat przed ich zrobieniem, jednak z uwagi na niepełnoletniość i nieprzychylne opinie rodziny odkładali to wydarzenie na później. Jedna z moich rozmówczyń, 29-letnia mieszkanka Poznania, dokładnie pamięta moment, w którym postanowiła zrobić sobie dredy:

\footnotetext{
${ }^{5}$ Ponadto prowadziłam notatki z nieformalnych rozmów, w których pojawiał się temat włosów i dredów, jednak nie wliczam ich w zestaw wywiadów.
} 
Jeśli chodzi o moje dredy, to tak, decyzję podjęłam pierwszą, że chcę, jak miałam, nie wiem, naście lat, jak byłam w gimnazjum, pierwsza, druga gimnazjum, więc to potrwało jeszcze z pięć lat, zanim je zrobiłam. (...) No ja pamiętam pierwszą sytuację, kiedy chciałam dredy. Byłam na jakiejś wycieczce, widziałam pierwszy raz na żywo w Berlinie dredy i po prostu wiedziałam. (...) Jak to zobaczyłam, to się zakochałam (K01).

Rozmówczyni zarabiała też na robieniu dredów innym ludziom. Mając dziesięć lat doświadczenia, doskonale znała tendencje i mody, które sprowadzały do niej klientów. Tych jej nie brakowało - piętrzące się zlecenia zmuszały mnie do wielokrotnej zmiany terminu spotkania. Każdego traktowała indywidualnie, starając się zrozumieć, dlaczego zdecydował się na taką fryzurę. Na tej podstawie stwierdziła, że niektórzy niewiele wiedzą o praktycznej stronie dredów. Nie są przygotowani na ból ani na to, że efekt finalny może się całkowicie różnić od tego na zdjęciu. Tłumaczyła im, że każde włosy mają inną strukturę i nie zawsze będą wyglądały tak, jak oczekiwano. Większość wtedy wychodziła i już nie wracała. Pytana o przedział wiekowy swoich klientów dreadmakerka odpowiedziała:

Jeżeli chodzi o wiek, kim są ci ludzie i czym się zajmują, to przekrój jest ogromny. Ostatnio miałam dziewięciolatka. (...) Półtora roku zapuszczał włosy, więc miał z siedem lat, jak na to w padł, szok. No, to był najmłodszy, jakiego robiłam. A najstarszej pani się boję spytać o wiek, bo wygląda wiekowo, ale myślę, że ma około sześćdziesięciu lat. (...) To nie jest tak, że to jest przekrój dwadzieścia-dwadzieścia pięć lat (K01).

Rozmówcy już na poziomie motywacji prezentowali odmienne doświadczenia. Było to m.in. zainteresowanie muzyką, chociaż i w tej materii różnili się od siebie. Nie wszyscy bowiem interesowali się domniemanym źródłem dredów, czyli muzyką reggae. W zasadzie stanowili oni mniejszość (dwie osoby). Jedna z rozmówczyń, która stwierdziła, że za jej decyzją nie stały „absolutnie żadne jakieś rastamańskie pomysły”6: „byłam zakochana w Kornie ${ }^{7}$ i po prostu tam był Munky. (...) On miał dredy i ja musiałam po prostu, nie. Ogólnie na pewno nie Bob, na pewno nie Bob Marley" (K01).

Niektórzy, mimo że informacje o dredach czerpali z literatury i filmów poświęconych rastafari, nie utożsamiali się z jego ideologią. Jedna osoba uznała, że jako głęboko wierząca katoliczka nie może się z nim identyfikować (K02). Wśród motywacji znalazły się również względy praktyczne. Jedna z moich rozmówczyń uznała, że codzienne mycie, suszenie i układanie włosów utrudniało jej podróżowanie. Jednocześnie stwierdziła, że dredy kojarzą jej się z buntem, wolnością i powrotem do bardziej naturalnego trybu życia. Podobnie postąpił także rozmówca, który wyżej od zainteresowań muzycznych postawił wygląd i praktyczność fryzury:

\footnotetext{
${ }^{6}$ Słowa użyte przez rozmówczynię.

${ }^{7}$ Amerykański zespół wykonujący muzykę z gatunku nu metal.
} 
Muzyka? Myślę, że nie aż tak. (...) Bardziej względy estetyczne. Zrobiłem dredy ze względów estetycznych, nie ideologicznych. Zrobiłem dlatego, że mi się podobały. Musiałem to zrobić, bo wiedziałem, że jak ich nie zrobię, to zetnę włosy, bo mnie denerwowała grzywka (M01).

Dredy zatem mogą, ale nie muszą wynikać z dorastania w określonych warunkach i wśród osób słuchających konkretnego gatunku muzycznego. Sama muzyka, która przyczyniła się do podjęcia decyzji o zapuszczeniu włosów bądź doczepieniu gotowych, długich dredów, była zróżnicowana lub nie miała żadnego znaczenia. Dwie osoby wprost przyznały, że nie odnoszą swojej fryzury do muzyki, światopoglądu czy określonej subkultury. Mówiły o pewnej estetyce, z którą się identyfikowali lub o względach praktycznych, które pozwalały między innymi na długie wyjazdy bez konieczności codziennego mycia włosów. Dla nich dredy były fryzurą, która przypadła im do gustu i odpowiadała na ich potrzeby.

Z doświadczeń moich rozmówców wynika, że w ich otoczeniu społecznym dredy często nie są postrzegane jako „normalna” fryzura. Podzielili się ze mną refleksjami na temat pracodawców traktujących ich włosy jako wyznacznik specyficznych światopoglądów i zachowania, który brano pod uwagę przy zatrudnieniu, a także szkół, których statuty zabraniały uczniom noszenia dredów. Najczęściej jednak to członkowie rodziny - rodzice i dziadkowie - dawali moim rozmówcom do zrozumienia, że nie odpowiada im taka fryzura u ich dzieci czy wnuków. Ci, którzy wpadli na pomysł zrobienia sobie dredów w szkole podstawowej, gimnazjum czy liceum, odłożyli te plany ze względu na brak zgody ze strony rodziców lub przez samą obawę przed ich negatywną reakcją. Osiągnięcie pełnoletniości stanowiło warunek postawiony rozmówcom przez ich rodziców. Do tego czasu każda trwała zmiana musiała być skonsultowana z rodziną, która zwykle się na nią nie zgadzała.

Tak było między innymi w przypadku rozmówczyni, która zrobiła sobie dredy w wieku dwudziestu jeden lat. Zapytana, dlaczego nie zrobiła tego wcześniej, powiedziała: „Myślę, że rodzice nie wyraziliby zgody, zanim miałam osiemnaście lat. A już tutaj nie mieli co mówić. Moja decyzja i moje też pieniądze, więc trochę inaczej" (K03). Pełnoletniość stanowi również kryterium, które należy spełnić, by umówić się na zrobienie dredów u profesjonalisty. W innym wypadku wymagają oni pisemnego oświadczenia, w którym rodzic lub opiekun zgadza się na wykonanie fryzury u swojego dziecka/podopiecznego:

Była raz taka dziewczynka u mnie. (...) Miała tylko trzy z tyłu, więc to nie był jakiś tam problem. Jakby chciała całą głowę, byłaby nieletnia i przyszła bez jakiejś tam zgody od rodziców, to bym jej nie przyjęła (K01).

Poza wiekiem barierą przed dredami jest cena zabiegu, która sięga współcześnie kilkuset złotych. Wysoki koszt usługi uniemożliwia ją młodym, niezarabiającym osobom - muszą na nią zarobić lub poprosić o finansową pomoc rodziców. Jak zauważyła rozmówczyni K01: „to rodzice płacą za dredy i decydują o tym, czy dziecko może lub nie może ich nosić". 
Problemy z dredami pojawiają się także na poziomie instytucjonalnym. Gimnazjum, do którego chodził jeden z moich rozmówców (M01), uznawało je za wygląd niezgodny ze statutem szkoły, karany obniżeniem oceny z zachowania lub w skrajnym przypadku wydaleniem z placówki. Gdy był uczniem drugiej klasy, do gimnazjum dołączył chłopak, którego dredy wywołały spore kontrowersje:

Mówili mu, że albo ścina dredy, albo nie przyjmują go do szkoły. (...) Szkoła powoływała się na jakiś tam zapis w statucie, że uczeń musi być schludny i tak dalej. Za nieschludne uznali dredy (M01).

Chłopak nie pozbył się swoich włosów, a dyrekcja szkoły usunęła go z placówki. Choć mojego rozmówcy (M01), który w tym czasie miał kilka dredów, nie spotkały tak daleko idące konsekwencje, on również doświadczył nieprzyjemności ze strony nauczycieli. Podczas wywiadu wspominał docinki o braku higieny czy stawianie przed nim dużo większych wymagań niż wobec pozostałych uczniów. Nie spodobało mu się takie traktowanie. Uznał, że uczniowie mają prawo ubierać się i czesać tak, jak chcą, bez narażenia na obniżenie oceny zachowania czy odebranie statusu ucznia. Postanowił dołączyć do sekcji prawnej samorządu studenckiego, gdzie podjął działania na rzecz zmiany zapisu dotyczącego wyglądu w statucie szkoły. Chodził na rady pedagogiczne, podczas których przedstawiał swój punkt widzenia nauczycielom i dyrekcji. Wysłuchiwał innych uczniów, którzy mieli obiekcje w stosunku do relacji między nimi a nauczycielami. Starania te nie przyniosły jednak żadnych rezultatów, a statut szkoły nadal ma zapis dotyczący wyglądu uczniów. Narracja rozmówcy była jedyną, która dotyczyła tak skrajnego doświadczenia związanego z dredami w szkole. Być może wynika to z tego, że należy on do nielicznych, którzy dredy nosili już w gimnazjum. Dwie z moich rozmówczyń (K01 i K03) o posiadaniu dredów zdecydowały w podobnym czasie, jednak zrobiły je dopiero w liceum i na studiach, gdzie nie obowiązywały tak surowe zasady dotyczące wyglądu.

Dredy mogą stanowić utrudnienie bądź ułatwienie zdobycia zatrudnienia. Jedna z moich rozmówczyń z powodu fryzury straciła pracę kelnerki w hotelowej restauracji. Po kilku miesiącach od podjęcia pracy miejsce zostało poddane rutynowej kontroli sanitarno-epidemiologicznej, po której moja rozmówczyni (K01) dostała wypowiedzenie ${ }^{8}$. Poszukiwania nowej pracy często kończyły się niepowodzeniem, ponieważ „właściciel nie zgadzał się na dredy”:

(...) pojechałam do jakiegoś hotelu, prawie za miastem, ale już byłam zdesperowana. Poszłam do tego hotelu i kiedy na recepcji składałam $\mathrm{CV}$, też babka powiedziała, że jakbym ścięła dredy, to nie ma sprawy, bierze mnie. (...) Ale nie, stwierdziłam, że póki nie mam dzieci i zobowiązań takich konkretnych, to pierdzielę, będę pracować na kasach. A na kasach chcieli wszystkich (K01).

\footnotetext{
${ }^{8}$ Z narracji K01 wynikało, że inspektorom nie spodobał się fakt posiadania dredów przez osobę przyjmującą zamówienia i wydającą jedzenie gościom hotelowym.
} 
Doświadczenie rozmówczyni nie dowodzi jednak o uprzedzeniach wszystkich polskich pracodawców. Wśród moich rozmówców znalazły się również takie, którym udało się znaleźć zatrudnienie bez problemów. Jedna z osób starała się o pracę na stacji benzynowej:

Pamiętam, że chciałem iść do pracy na wakacje w 2012 roku. (...) Wysłałem CV, zaprosili na rozmowę i przyszedłem. Gadamy, gadamy, i nie było podczas tej rozmowy żadnego tematu o dredach. Jakbym ich nie miał. Nie było żadnego kłopotu. (...) Bałem się, że pomyślą, że na stanowisku sprzedawcy będę odstraszać ludzi. Ale nikt, absolutnie, ani klienci, ani szefostwo nie mieli pretensji (M02).

Rozmówczyni, która sama miała dosyć nieprzyjemne doświadczenia związane z dredami w miejscu pracy, opowiadała o klientce, która właśnie dzięki nim została zatrudniona: „zrobiła sobie dredy u mnie. Jak miała całą głowę, to poszła do DPD do pracy i babka powiedziała jej, że nie jest szarą myszką przynajmniej i dlatego ją wzięła. Bo ludzie w dredach to takie konkret osoby, więc ją wybrała..." (K01). Z powyższego wynika, że określone wyobrażenie o osobie noszącej dredy może zarówno utrudnić, jak i ułatwić zdobycie pracy. Pracodawczyni, którą spotkała klientka mojej rozmówczyni, przez pryzmat włosów postrzegała ją jako osobę odważną, kreatywną i otwartą, co czyniło ją potencjalnie dobrą pracowniczką. Jednak niezależnie od tego, czy ma wydźwięk pozytywny, czy negatywny, stereotyp wciąż jest stereotypem i wynika z określonych wyobrażeń o świecie.

W narracjach rozmówców moją uwagę zwróciło odmienne postrzeganie dredów w zależności od płci osoby, która je nosi. Schemat, który powtarzał się niemal za każdym razem, to odbieranie stereotypowo rozumianej „esencji” płci, czyli kobiecości i męskości. Dredy miały sprawiać, że kobiety są mniej „kobiece”, a mężczyźni mniej „męscy”. Problem ten dotyczył przede wszystkim kobiet. Po zmianie fryzury bardzo często słyszały uwagi na temat swojej urody. Jedna z rozmówczyń przy pomniała sobie, że „babcia do dzisiaj tego nie przełknęła. Cały czas mówi o ich ścięciu. Mówi, że nie wyglądam jak dziewczyna, że to nie jest takie dziewczęce" (K04). Jej odpowiedź wskazywała, że tego typu komentarze padają najczęściej ze strony rodziny - to właśnie bliscy mają największe obiekcje wobec nowego wizerunku swoich córek i wnuczek.

Antykobiece wyobrażenia o dreadach są również motorem napędzającym mowę nienawiści kierowaną w stronę moich rozmówczyń przez nieznajomych:

Koleś (...) po prostu obchodził mnie dookoła, bo nie wierzył, że jestem dziewczyną. I bardzo głośno komentował. Pierwszy raz miałam taką sytuację. Bo był strasznie chamski w tym i był w szoku, że jak, laska i dredy? Nie rozumiał (K01).

Opisane wyżej sytuacje mogłyby sugerować, że skoro dredy są niekobiece, a dziewczyny je noszące mylone są z mężczyznami, to taka fryzura powinna być atrybutem męskości. Tak jednak nie jest. Moi rozmówcy wspominali: „zdarzało się, że szedłem do znajomych na imprezę i pytali mnie, co mam z tyłu. Ja mówię: 
dredy. A oni, że wyglądam jak dziewczynka” (M04); „Pamiętam, że jak wtedy miałem dredy, to nie nosiłem zarostu i cały czas mnie mylili z kobietą. Stojąc w kolejce, ktoś szturchał mnie w ramię i mówił «a pani coś tam», a ja się odwracałem i mówiłem: «Jestem mężczyzną». Czasami mnie to denerwowało" (M02).

Podczas rozmów często okazywało się, że moi rozmówcy podzielają stereotypy, które używano w stosunki do nich samych. Jedna z moich rozmówczyń (K06), która rozplątała swoje dredy, powiedziała: „Ja dredy bardzo lubiłam, ale jak potem się pierwszy raz wykąpałam tak naprawdę, to tak stałam pod prysznicem i tak mogłam normalnie spienić i potem rozczesać, czułam się jak kobieta z powrotem". Tymi słowami wydawała się potwierdzać to, co wcześniej sugerowała jej mama - że dredy $\mathrm{w}$ istocie są niekobiece, ponieważ uniemożliwiają codzienne praktyki, takie jak mycie i układanie włosów, które rozmówczyni wiązała z poczuciem swojej kobiecej tożsamości. Z jej słów wynikało, że rozplątanie dredów „zwróciło” jej brakującą dotychczas kobiecość. Jeden z moich rozmówców miał podobne zdanie na temat dredów u kobiet, mimo że sam je nosił. Jego zdaniem dredy zabierają miejsce długich i gładkich włosów, które powinny być immanentnym atrybutem kobiety:

Jakby moja dziewczyna miała dredy, to chyba bym nie chciał, żeby miała. Bo lubię tę konsystencję włosów, że sobie pomacasz i tak dalej. A dredy są sztywne. To jest inna sprawa, dredy u kobiety (M02).

Osoby te uznały dredy za fryzurę antykobiecą, a długie i gładkie włosy za wyjątkową cechę charakteryzującą płeć żeńską. Z analogiczną opozycją zmagały się rozmówczynie amerykańskiej profesor black studies Ingrid Banks (2000). Badane przez nią kobiety musiały uporać się z wyobrażeniami na temat swoich afrykańskich włosów, które stanowiły widok społecznie niepożądany, niekobiecy i brzydki. Zależność między dredami a włosami rozczesanymi może być częściowo analizowana w podobny sposób, jak relacja między afro a włosami prostymi. Amerykańska pisarka i feministka bell hooks ${ }^{9}$ (1989: 382-388) określiła wełniste afro mianem „złych włosów”, których przeciwieństwo stanowią „dobre włosy" - długie, proste, gładkie i jasne. Z narracji moich rozmówczyń wynika, że w Polsce „złymi włosami” mogą być właśnie dredy, które, nawet jeżeli są długie, są też sztywne, szorstkie i wymagające zupełnie innej pielęgnacji. Z doświadczeń badanych wynika, że dredy dokonują czegoś w rodzaju „odpłciowienia” - zaprzeczają zarówno stereotypowo pojmowanej kobiecości, jak i męskości.

\section{Stereotypy w działaniu}

Część pytań, które zadawałam moim rozmówcom, dotyczyła społecznego odbioru dredów. Nie znalazłam osoby, której fryzura nie wzbudzałaby żadnych emocji wśród rodziny, przyjaciół czy przypadkowo spotkanych osób. Wobec wszystkich

\footnotetext{
${ }^{9}$ Pseudonim artystyczny Glorii Jean Watkins.
} 
przynajmniej raz zastosowane zostało pewne wyobrażenie i opinia wypracowana na gruncie tego wyobrażenia. Reakcje na dredy wynikały z niewiedzy i stereotypów, które obejmowały zarówno samą fryzurę, jak i osoby, które ją noszą. Wyobrażenia te funkcjonowały na wielu płaszczyznach. Dotyczyły nie tylko płci kulturowej, o której wspomniałam, lecz także higieny, społecznie konstruowanej kategorii piękna i brzydoty, poglądów politycznych oraz określonych zachowań przypisywanych różnym subkulturom.

Część stereotypów miała wydźwięk pejoratywny: „Pytano mnie na przykład o to, czy palę, bo z tym wiąże się ten wygląd, że dredy i muzyka reggae, to ludzie mnie posądzali od razu o to, że muszę palić właśnie marihuanę, a ja tego nie robię” (K02). „Kiedyś tylko zaczepił mnie dziadek w Wolsztynie, taki pijaczek zapytał, czemu się oszpeciłam. Pamiętam, że... za każdym razem pytali, czy się myje dredy, jak się myje dredy” (K04). „Zdarzyło się, że któraś z nad wyraz zadbanych panien oburzała się: jak można nosić coś takiego na głowie, i to dziewczyna! Bardzo dużo osób posądzało mnie o słuchanie Boba Marleya i muzyki reggae. Uważali też, że na pewno jestem hipisem o bliskich komunizmowi poglądach politycznych” (K05). „Moja ulubiona historia, to jest jakaś taka parka takich... Wyglądali na takich spijaczonych ludzi i kobieta odezwała się za moimi plecami: «bo się porzygam». Nie chodziło jej raczej o to, że za dużo wypiła, tylko że moje dredy są okropne” (K01). „Słyszałem na przykład, że mam gówno na głowie. No że mam robale w głowie, że nie mam szczotki w domu. No i często pytania, czy mam coś do palenia” (M03). "Coś takiego było, ale to jakieś dziecko mówiło małe, szłam ulicą i słyszałam za sobą: «Czy ta pani nie myła włosów?»” (K03). „Raz spotkałem się z taką nietolerancją. Na żużlu. Jeden z kibiców chwycił mnie na bok i pytał, co ja mam na włosach i tak dalej. A to był kibic tego samego klubu co ja! Powiedział, że mam zdjąć barwy albo pozbyć się tych włosów" (M04).

Część doświadczeń moich rozmówców wynikała jednak z wyobrażeń o charakterze pozytywnym. Zarówno przypadkowo spotkane osoby, potencjalni pracodawcy, bliscy, jak i sami badani przy porządkowywali dredy do takich kategorii jak: otwartość, pomysłowość, kreatywność czy wolność. "Zawarłam mnóstwo znajomości przez dredy. Często nieznajome osoby w dredach witały się ze mną na ulicy, uśmiechały. Także Ci bez dredów zagadywali, chwalili fryzurę. (...) Panie w przedszkolu były uradowane mamą w dredach i opowiadały o swoich dzieciach, które chcą lub mają dredy" (K05). „Jest jakieś takie przekonanie, że ludzie w dredach są bardziej otwarci, więc sami też się do nich otwierają. Nie jest taki sztywniak, można zagadać, na pewno jest wyluzowany” (K01). "Czasami było fajnie, jak przechodzi dresik i mówi «fajne pająki»! Zazwyczaj jest spoko, na palcach jednej ręki mogę policzyć jakieś osoby, które tam ewidentnie źle zareagowały" (K01).

Dredy moich rozmówców odbierane były jako sygnał, że osoba je nosząca należy do pewnej grupy społecznej czy subkultury, ma określony charakter i zainteresowania. Dla wielu nowo poznanych osób byli fanami muzyki reggae, mimo że jej nie słuchali. Pytano ich o narkotyki, mimo że ich nie spożywali. Uznawano za osoby zaniedbane i brudne, mimo że dbali o higienę. Zdarzało się, 
że przechodnie, klienci tego samego sklepu czy uczestnicy tego samego koncertu dotykali włosów moich rozmówców, co naruszało ich przestrzeń osobistą. Jedna z nich pamiętała, jak ciekawscy ludzie bez skrępowania sięgali po jej dredy. Z czasem zachowanie to zaczęło jej przeszkadzać do tego stopnia, że stało się jednym z powodów, przez które rozplątała włosy.

W niektórych przytoczonych fragmentach rozmów wybrzmiewała teza, że większość osób noszących dredy to „otwarte umysły” - osoby odważne, żądne przygód, uwolnione od społecznej kontroli nad wyglądem. Jest to jednak ocena subiektywna. Jedna z moich rozmówczyń zapytana o to, czy w jakiś sposób utożsamia się z istniejącymi wyobrażeniami na swój temat, przy pomniała sobie czasy studiów: „Pamiętam, że jak mieliśmy wykłady, to wykładowca walił do mnie cały czas jakimiś tekstami. Oczekiwał, że będę z nim rozmawiać, że będę bezczelna, że będę do przodu strasznie, bo przecież mam dredy. Że ja powinnam rozmawiać z nim, a ja nie byłam taka" (K01).

Moi rozmówcy najczęściej starali się nie zwracać szczególnej uwagi na podobne zaczepki. Przyzwyczajali się do nich, jak i przykrych komentarzy. Nie oznacza to jednak, że ich nie dotykały. Jedna z moich rozmówczyń przyznała: „kilka razy też smutno było, jak ktoś mówił, że się nie myję, ale w sumie się nie przejmowałam, bo wiedziałam, że się myję" (K06). Oprócz wyraźnie pejoratywnych określeń osoby noszące dredy spotykały się również z pozytywnymi reakcjami, które zdecydowanie przeważały nad tymi negatywnymi. Nieznajomi zaczepiali ich, mówiąc, że mają piękne „pająki”, „baty”, „macki” czy „kluski”. Dredy stanowiły pretekst do nawiązywania nowych znajomości, które przeradzały się w głębokie przyjaźnie lub stałe związki. Według jednej z moich rozmówczyń społeczny odbiór dredów wynika z ich stanu. Zadbane i czyste nie wzbudzają jej zdaniem takich reakcji, jak powyginane i nieuporządkowane.

Jednym ze stereotypów na temat dredów, które wskazali moi rozmówcy, jest przypisanie ich pochodzenia z Jamajki i powiązanie z duchowością pierwszych członków ruchu rastafari. Nie jest to oczywiście nieprawdą, jednak - jak wykazałam w pierwszej części tekstu - fryzura ta jest elementem wielu kultur i religii. Problem ten sięga jednak dużo głębiej niż sam fakt niewiedzy i prowadzi niekiedy do poważnych konfliktów. Jedna z klientek mojej rozmówczyni (K01) ścięła dredy po kilku tygodniach od zabiegu. Dziewczyna tłumaczyła, że decyzję tę podjęła po negatywnych reakcjach jej czarnoskórych znajomych w Londynie. Mieli uznać, że dziewczyna bez pochodzenia afrykańskiego nie ma prawa do noszenia dredów, że w ten sposób profanuje ich dziedzictwo kulturowe i rodzime tradycje. Mieli grozić jej obcięciem włosów. Niestety moja rozmówczyni (K01) nie znała szczegółów wydarzenia, mnie natomiast mimo licznych prób nie udało się skontaktować z tą osobą. Wyrażeniami, które usłyszała w Polsce, były natomiast: "to nie jest twoje", "tak nie noszą się biali", „zdejmij to".

Termin „przywłaszczenie kulturowe” (cultural appropriation) oznacza przejęcie i wykorzystywanie elementów jednej kultury przez członków innej (Young, Brunk 2012; por. Forte 2017). Od zapożyczenia, które znajdziemy w każdej niemal kulturze (Linton 1937: 405-406), przywłaszczenie kulturowe różni się tym, że 
polega na zawłaszczeniu symboli i zachowań określonej grupy, dla której mają one istotne znaczenie społeczne i religijne. Wykorzystanie ich w zupełnie innym kontekście kulturowym, pozbawienie pierwotnego znaczenia symbolicznego lub jego trywializacja może być uznane przez tę grupę za akt profanacji. Zjawisko ma najczęściej charakter kolonialnej relacji władzy i dominacji - społeczność przywłaszczająca jest zwykle większością o wyższym statusie społecznym, ekonomicznym, politycznym czy militarnym od grupy, której symbole są przedmiotem kradzieży. W ten sposób włączone w popkulturę artefakty o pierwotnie odmiennym znaczeniu społecznym stanowią przejaw folkloryzmu, czyli wybiórczego traktowania elementów kultury tradycyjnej, które wykorzystywane są w celowo zaaranżowanych i kontekstowo odmiennych sytuacjach (Burszta 1969: 69-90).

Wobec powyższego próbowałam zrozumieć fenomen dredów i możliwe znaczenia nadawane dredom w innych kulturach, które starałam się zarysować w pierwszej części tekstu. Moim celem nie było opowiedzenie się po którejś ze stron konfliktu i wykazanie, która ma rację lub się myli. Interesowały mnie raczej procesy, które do tego konfliktu doprowadziły. Sam problem przywłaszczenia kulturowego jest jednak dużo bardziej złożony, związany z problematyką przemocy kolonialnej i rasizmem, a przez to wymagający odrębnych badań i analizy teoretycznej.

\section{Podsumowanie}

Rzeczywistość badanych przeze mnie osób ukazała funkcjonujące w Polsce wyobrażenia i wynikające $z$ nich uprzedzenia wobec dredów i ich właścicieli. W artykule skoncentrowałam się na czynnikach wpływających na decyzję o ich wykonaniu, społecznych reakcjach obnażających funkcjonujące stereotypy, wynikających z nich uprzedzeniach i ich społecznych konsekwencjach, wpływie na kulturowo konstruowane ideały kobiecości i męskości oraz, częściowo, przywłaszczeniu kulturowym.

Moi rozmówcy zrobili sobie dredy z uwagi na ich wymiar praktyczny i estetyczny, choć dużą rolę w decyzjach odgrywała także muzyka, którą, wbrew powszechnej opinii, było nie tylko reggae. Dla niektórych dredy były po prostu ciekawą fryzurą, którą nosili w ramach eksperymentu. Nie wiązali z nimi żadnych ideologii, światopoglądów czy kwestii religijnych. Nie stanowiły one "symbolu publicznego" (Obeyesekere 1981: 13), w którym krystalizowałyby się osobiste czy duchowe doświadczenia jednostki, ani wyróżnika kulturowego w rozumieniu Olivelléa czy Bogina. Podczas badań dowiedziałam się, że wielu ludzi myśli o ich noszeniu dlatego, że są po prostu modne lub ponieważ nosi je wiele gwiazd światowej sceny muzycznej (K01). Tym, co łączyło badane osoby, był fakt, że żadna z nich nie deklarowała się jako członek ruchu rastafari, zatem żadna z nich nie potwierdzała nakładanego na nich stereotypu „rastamana”.

Zgodnie z koncepcjami fasady osobistej i wrażenia wywołanego (Goffman 2010: 47-49) fryzura może być związana z określonymi wyobrażeniami 
nakładanymi na jej użytkownika lub stanowić zamierzony przez niego komunikat niewerbalny. Nie oznacza to jednak, że użytkownik ten nie jest świadomy znaczenia swojego uczesania. Może on, tak jak moi rozmówcy, nosić ją z innego powodu. Osoby z ich otoczenia społecznego, nie mając świadomości lub nie zważając na powód zmiany fryzury, nakładały na moich rozmówców wyobrażenie, które - ich zdaniem - odpowiadało powierzchowności. Erving Goffman stwierdza, że nie znając danej osoby, obserwatorzy mogą czerpać wskazówki z jej zachowania i wyglądu, odnosząc do niej wcześniejsze doświadczenia z osobami podobnymi lub zastosować sprawdzone stereotypy. Wśród opisanych przez Watsona mieszkańców San Tin długie i sfilcowane włosy nędzarzy wywoływały skojarzenia z ekshumowanymi zwłokami i budzącymi strach zjawami: śmiercią, chorobami i wszelkimi zarazami, których należało się tylko wystrzegać. Gdy żebracy pojawili się w San Tin, „wszystko, co się liczyło, to unikanie wszelkiego kontaktu z nimi" (Watson 1998: 188).

Możliwe, że wyobrażenia zastosowane przez otoczenie społeczne moich rozmówców wobec ich dredów wynikało z obecności w polskiej kulturze kołtuna - wspomniany tzw. kołtun męski wyglądał tak, jak współcześnie najczęściej wyglądają dredy. Na stereotyp dredów jako fryzury powstałej z zaniedbania i braku higieny wpływają także sposoby ich wykonania oraz utrzymywania. W gimnazjum i na początku liceum, kiedy sama szukałam informacji o dredach, fora internetowe podpowiadały takie techniki jak wcieranie cukru, jajek lub popiołu, które miały powodować zlepianie i kołtunienie włosy. Ani ja, ani żadna z osób, z którymi rozmawiałam, nie stosowała takich metod. Nieprawdą jest także, że dredów nie można myć.

Czy poprzez fryzurę moi rozmówcy wyszli ze strefy kontroli społecznej, o której pisał Hallpike (1969)? Ich doświadczenie świadczy o czymś zgoła przeciwnym, nawet w sensie dosłownym - byli jeszcze bardziej kontrolowani. Jedna z badanych przez mnie osób (K01) z powodu dredów straciła posadę kelnerki w hotelowej restauracji. Inna (M04) spotkała się z groźbami ze strony kibiców tego samego klubu sportowego. Przyjaciel jednego z moich rozmówców (K02) został zatrzymany przez policję $\mathrm{w}$ miejscu publicznym i poddany rewizji $\mathrm{w}$ poszukiwaniu narkotyków. Za noszenie dredów uczeń tej samej szkoły, do której chodził jeden z badanych (M01), został z niej wydalony. Przez wzgląd na fryzurę moi rozmówcy i rozmówczynie byli poddawani ocenie zarówno przez bliskich, jak i nieznajomych. Tylko jedna osoba wiązała swoje dredy z buntem, wolnością i powrotem do natury.

Opisany w artykule wachlarz reakcji na posiadanie dredów dał próbę wyobrażeń, które na ten rodzaj fryzury nakłada otoczenie społeczne uczestników badania oraz sposób ich interpretacji przez samych rozmówców. Zarówno krytyczne, jak i przyjazne nastawienie wobec noszących dredy wynika bowiem z określonych dyspozycji nabytych przez posługującego się nimi w życiu codziennym. Moi rozmówcy postrzegani byli przez swoich bliskich, pracodawców, nauczycieli czy przypadkowo spotkane osoby jako osoby celowo zaniedbujące się, buntownicze, ale również optymistyczne, rozgadane i łatwo nawiązujące 
kontakty. Wyobrażenia te odbierali na różne sposoby, z większością się jednak nie zgadzali, chociaż jednocześnie stosowali je wobec innych ludzi. Najczęściej deklarowali obojętność, mówiąc, że przecież sami wiedzą najlepiej, kim są.

\section{Bibliografia}

Agwuele, A. (2016). The Symbolism of dreadlocks and communicative Contents of Dreadlocks in Yorubaland. London: Palgrave Macmillan.

Ashe, B. (2015). Twisted: My Dreadlock Chronicles. Chicago: Agate.

Banek, K. (2010). Opowieść o włosach. Zwyczaje - rytuaty - symbolika. Warszawa: Wydawnictwo TRIO.

Banks, I. (2000). Hair Matters: Beauty, Power, and Black Women's Consciousness. New York, London: New York University Press.

Berg, C. (1951). The Unconscious Significance of Hair. London: Allen \& Unwin.

Bogin, B. (2008). On Tantric Hairstyles in Tibetan Buddhism. History of Religions, 48(3), 85-109.

Brückner, A. (1927). Słownik etymologiczny języka polskiego. Kraków: Krakowska Spółka Wydawnicza.

Burszta, J. (1969). Kultura ludowa - folkloryzm - kultura narodowa. Kultura i Społeczeństwo, 13(4), 69-90.

Cukierska, A. (2014). Plica Polonica. Bytom: Kronika.

Douglas, M. (2004). Symbole naturalne: rozważania o kosmologii, przeł. E. Dżurak. Kraków: Wydawnictwo Uniwersytetu Jagiellońskiego.

Forte, M.C. (2017). Cultural Appropriation, Cultural Exploitation, Cultural Genocide: Problems of Neoliberal Diversity Management. Źródło: https://zeroanthropology.net/2017/12/19/ cultural-appropriation-cultural-exploitation-cultural-genocide-problems-of-neoliberal-diversity-management/ [dostęp: 25.06.2020].

Gąsiorowski, S. (2013). Plica Polonica, czyli kołtun polski w XVI-XVII w. Rocznik Przemyski, XIL, 3-16.

Goffman, E. (2010). Człowiek w teatrze życia codziennego, przeł. H. Śpiewak. W: A. Chałupnik (red.), Antropologia widowisk - zagadnienia i wybór tekstów (s. 47-60). Warszawa: Wydawnictwo Uniwersytetu Warszawskiego.

Hallpike, C. (1969). Social Hair. Man, 4, 256-264.

Hiltebeitel, A., Miller, B. (1998), Hair: its power and meaning in Asian Cultures. Albany: State University New York Press.

hooks, b. (1989). From Black Is a Woman's Color. Callaloo, 39, 382-388.

Leach, E. (1958). Magical Hair. Journal of the Royal Anthropological Institute of Great Britain and Ireland, 88(2), 147-164.

Linton, R. (1937). One hundred percent American. The American Mercury, 40, 405-406.

Malinowski, B. (1957). Życie seksualne dzikich w pótnocno-zachodniej Melanezji: miłość, matżeństwo i życie rodzinne u krajowców z Wysp Trobrianda Brytyjskiej Nowej Gwinei, przeł. J. Chałasiński. Warszawa: Wydawnictwo Książka i Wiedza.

Obeyesekere, G. (1981). Medusa's hair: An Essay on Personal Symbols and Religious Experience. Chicago, London: University of Chicago Press.

Olivelle, P. (1998). Hair and Society: Social Significance of Hair in South Asian Traditions. In: A. Hiltebeitel, B. Miller (eds.), Hair: its power and meaning in Asian Cultures (pp. 11-49). Albany: State University New York Press. 
Pruszyński, J.J., Putz, J., Cianciara, D. (2013). Plica neuropathica - historia problemu i opis przypadku. Hygeia Public Health, 48, 481-485.

Rooks, N. (1996). Hair Raising: Beauty, Culture and African American Women. New Brunswick: Rutgers University Press.

Saitoi, T.O., Beckwith, C. (1980). Maasai. New York: Harry N. Abrams.

Synnott, A. (1987). Shame and Glory: A Sociology of Hair. The British Journal of Sociology, 38(3), 381-413.

Targońska, A. (1998). Symbolika włosów i manipulowanie włosami w kulturze ludowej. Lud, 82, 157-176.

Tarlo, E. (2016). Entanglement. The Secret Life of Hair. London: Oneworld.

Tomicki, R. (1987) Poza społeczeństwem - w pobliżu boskości. Przyczynek do rozważań nad symboliką włosów. Polska Sztuka Ludowa, 41, 169-176.

Tylor, E.B. (1898) Cywilizacja pierwotna. Badania rozwoju mitologji, filozofji, wiary, mowy, sztuki i zwyczajów, t. 2, przeł. A. Kowerska. Warszawa: Wydawnictwo "Głosu” w drukarni F. Csernaka.

Udziela, M. (1891). Medycyna i przesądy lecznicze ludu polskiego. Przyczynek do etnografii polskiej. Warszawa: Skład Główny w Księgarni M. Arcta.

Watson, J.L. (1998) Living ghosts: Long-haired destitutes in Colonial Hong Kong. In: A. Hiltebeitel, B. Miller (eds.), Hair: its power and meaning in Asian Cultures (pp. 177-194). Albany: State University New York Press.

Young, J.O, Brunk, C.G. (2009). The Ethics of Cultural Appropriation. Oxford: Wiley-Blackwell.

\section{SUMMARY}

Stereotyping hairstyle: Hair stereotypes in the experiences of people wearing dreadlocks in Poland

The article is an anthropological analysis of the symbolism of hair and the socio-cultural meaning associated with hairstyles based on the example of dreadlocks in Poland, explored during field research conducted by the author in 2016-2017. The text presents the symbolism of dreadlocks in various cultural contexts and an analysis of hair stereotypes in the experiences of people wearing dreadlocks in Poland. This hairstyle is part of many cultures, in which it has different names and performs different functions. Depending on the place, it may symbolize the religiosity of an individual, a political manifesto, mourning or fashion. The individual motives to wear such a hairstyle are not always associated with a particular ideology or policy, but the decision to do so is not completely free from significance. The main part of the article, discussing the Polish context, has been based on interviews conducted as part of the author's M.A. thesis.

Keywords: hair, dreadlocks, stereotype, field research, gender 